\section{AUTOMOBILE RESEARCH}

A CONSIDERABLE amount of the work at the A Research Laboratories of the Institution of Automobile Engineers is being done for Government departments, and since it is of a confidential nature may not be shown to a visitor. Nevertheless, at the recent inspection of the laboratories by members of the Automobile Research Committee and representatives of affiliated firms, there were several important investigations to be seen in actual operation. Usually, work of this nature arises directly out of the problems of the industry either in the form of an explicit question such as that of the fatigue strength of crankshafts, or from the more nebulous query as to whether aeration of the lubricant is a determining factor in the cause of bearing troubles, and these two cases are representative of the work being done at the Institution's Laboratory.

Three investigations into the aeration and frothing of lubricants were to be seen in operation on the above occasion. In the Chemical Laboratory, tests were being made to ascertain the frothing tendency of different oils at atmospheric pressure but variable temperature. In the Chassis Laboratory, a transparent bearing of plastic material has been arranged so that the behaviour of aerated oil can be observed, and it was of interest to note that, under the limited conditions permissible, the oil film at the pressure side was not ruptured. In the General Laboratory, a typical installation comprising a tank, aero-engine sump, oil cooler, pumps and filters has been set up in order to study the effect of high altitudes on the frothing occurring in an aircraft engine lubricating system. It is intended to run this at reduced pressures and to observe the amounts of froth formed in different parts of the system.

An investigation of a somewhat related character is that on the durability and wear of bearings, for which machines of two types have been developed. In these the test bearings are in the form of bushes cast or inserted in a steel shell and fitted as the big end of a connecting rod. As an extension of the work on these two machines, tests on full-size engine bearings are in prospect on another machine of special design by which an alternating load is applied by an external lever arrangement. This machine is in the experimental stage, and it was particularly interesting to observe the electric strain gauge developed for measuring the actual load applied to the bearing and the torsionmeter for the cyclic torque variation. Both measurements are made while the machine is in operation.

Fatigue tests on full-size crankshafts are carried on in machines which are arranged so that one throw alone is under test at a time, thus enabling a number of separate investigations to be carried out on one multi-throw shaft. The machines are of the constant-strain type, and the method of test involves the repeated application of a known deflexion to the crank under test. Piston-ring scuffing is being studied in a single-cylinder water-cooled engine, arranged so that the jacket temperature and quantity of lubricant supplied can be varied under control. A gas producer of the Government "Emergency" type is being used to supply gas to a converted petrol engine in an investigation to ascertain the power loss involved in the conversion, and the methods by which this loss can be made good.

In addition to such work as is described above, the Laboratory staff is actively engaged in the preparation and circulation of abstracts of current technical literature bearing on matters affecting the automobile industry. Inquiries for technical information are dealt with by the library staff; the library contains a valuable collection of text-books, period. icals, pamphlets, research reports and reference volumes, thus providing the basis for the information service which supplements the research work of the Committee.

\section{EARTHQUAKE ACTIVITY IN NEW ZEALAND}

A $\mathrm{N}$ earthquake of considerable intensity shook $A$ the southern part of the North Island of New Zealand at approximately 11.35 a.m. local time on August 2. The epicentre of the shock was considered in New Zealand to have been some fifty miles from Wellington. The country districts most affected were Manawatu and Wairarapa, where the damage was considerable, though not on the same scale as at Wellington. The shock was estimated to have been as severe as that on June 24 (NATURE, July 4, pp. 18-19) though, according to human perception, it was of shorter duration. During the June earthquake damage was done to post office and power lines and water supplies, and many buildings were cracked. During the August shock hundreds of chimneys fell, many windows were broken and several of the buildings damaged in June were so severely shaken that it is likely they will have to be demolished. Some streets were temporarily closed to traffic and the City Engineer estimated that the damage in Wellington may run into hundreds of thousands of pounds.

The Dominion Observatory at Wellington has just (1942) published Bulletin No. S-64, "The Seismicity of New Zealand", by R. C. Hayes, which divides the islands into four seismic zones having marked differences in seismicity. Bastings has stated that the seismicity of New Zealand as a whole is high compared with other countries, due mainly to the relatively large number of earthquakes of the semidestructive type. The seismicity of any region is governed by both the maximum intensity of the shocks which occur and the frequency of the earthquakes. In the work of Hayes, the relative seismicity is obtained by multiplying the average number of shocks per decade $(1835-1940)$ in the area of RossiForel intensity 10 by 10 , the average of intensity 9 by 2 , and adding these to the average number of intensity 8. Freeman's work had previously shown that earthquakes of R.F. intensity 9 are twice as destructive as those of intensity 8 , and those of intensity 10 are ten times as destructive as those of intensity 8.

The average number of earthquakes per year (1921-40) is considered separately. Whenever earthquake swarms such as that in the Taupo region in the latter half of 1922 occur, only the stronger ones have been considered. On these facts, the four regions are: (I) The northern half of South Island and the south-eastern half of North Island with Cook Strait in the centre. This has an average of 97.8 earthquakes per year, and a relative seismicity of 11.5 ; (II) the central portion of North Island, average $23 \cdot 0$ earthquakes per year and relative seismicity $1 \cdot 1$; (III) the whole of the southern half of South Island, average $12 \cdot 1$ per year and relative 
seismicity 0.1 ; (IV) the extreme northern tip of North Island, average $1 \cdot 1$ earthquakes per year and relative seismicity 0.0 . In region $I$, the strongest shocks tend to congregate towards the east and south-east though the north-western part has the highest frequency for moderate or small shocks. The difference may be due to differences in the strength of crustal materials. In region II Taranaki is liable to semi-destructive shocks at infrequent intervals, "near" Auckland may have had violent shocks during 1835-36, and New Plymouth in 1819. In region III one semi-destructive shock between Mount Cook and Lake Wanaka has been definitely recorded though heavy shocks in the west coast sounds area have been mentioned in 1792, 1810 and $1826-27$.

Earthquakes within about $10^{\circ}$ of Wellington during May 1942 numbered 12. The greatest had intensity 4 (Rossi-Forel) on May 10, near Whakatane, and one on May 27 may have had intensity 3 at Upper Takaka. Two shocks on May 7 and May 21 respectively were felt at Rotorua. Additionally, five distant earthquakes were registered by the seismographs at Wellington, Christchurch, Auckland and Arapuni according to the provisional Bulletin $P-123$ published by the Dominion Observatory at Wellington.

\section{ORIGIN OF COSMIC RAYS}

A NEW hypothesis of the origin of cosmic rays and reports on its experimental testing in India and elsewhere are published in the Physical Review $(61,397$ and $407 ; 1942)$ by R. A. Millikan, H. V. Neher and W. H. Pickering. While retaining the fundamental basis of nuclear physics theories and transformations of rest mass into other forms of energy, former suggestions are reversed. The sun's heat is assumed to correspond with atom building going on in its interior, whereas cosmic rays are due to the complete annihilation process going on in interstellar space. The transformation of the rest mass of the atoms into cosmic-ray energy is postulated as complete instead of partial.

When the postulates are used, five definite cosmicray bands are predicted, each reaching the earth in a particular latitude, and four plateaux of unchanging cosmic-ray intensity, these plateaux being delineated by the latitudes of entrance of the successive bands. The bands are named as (i) a silicon band of energy $13 \cdot 2$ Bev., (ii) an oxygen-nitrogen band of mean energy $7 \cdot 1$ Bev., (iii) a carbon band of energy $5 \cdot 6$ Bev. and (iv) a helium band of energy 1.9 Bev.

To test these predictions it was necessary to measure directly vertical incoming cosmic-ray energies as a function of latitude. India is the most suitable place in the world for the most significant of the tests. While in India it takes 17 billion-volt, vertical, charged-particle rays to break through the blocking effect of the earth's magnetic field at the equator, about 13 billion only suffice on the other side of the earth in Peru.

A comparison of theory and experiment was made possible largely through generous support of the research by the Carnegie Corporation of New York, the Carnegie Institution of Washington and the India Meteorological Service. The results so far attained are the detection of the silicon band and the joint nitrogen-oxygen band, with less definite observation of the carbon and the helium bands.
The predicted values for latitudes and order of intensity are approximately of the same value as the observed. At least three of the four plateaux of constant cosmic-ray intensity were observed.

In the second paper, by Neher and Pickering, experimental details are given, although full description of the apparatus appears in the Review of Scientific Instruments under the title "A Cosmic-Ray Radio Guide" (13, 143; 1942). This instrument is a miniature radio-transmitter recording barometric pressure and atmospheric temperatures as well as the Geiger counter observations. By its aid, Geiger counter and electroscope observations were compared. The counter was found to give results very close to those of the electroscope and of comparable accuracy. When two or more counters are arranged as a cosmicray telescope, the radiation from a selected part of the sky only is recorded. Thus the energies recorded are delimited with considerably greater accuracy than by the use of the electroscope.

\section{FORTHCOMING EVENTS}

\author{
Tuesday, August 25
}

INSTITUTION OF CIVIL ENGINERRs (at Great George Street, Westminster, London, S.W.1), at 2.30 p.m.- Conference on "Civil Engineers and the Building Industry" (to be opened by Prof. C. E. Inglis, F.R.S.).

\section{APPOINTMENTS VACANT}

AppLICATIONS are invited for the following appointments on or before the dates mentioned:

Assistant to the Advisory OfFiogr in Plant Husbandry, and an ASSISTANT LECTURER IN THE DEPARTMENT OF BACTERIOLOGY The Secretary, West of Scotland Agricultural College, 6 Blythswood Square, Glasgow (August 28).

assistant to the Chief Researoh Offich of the Mentat ASSISTANT TO THE CHIEF RESEARCH OFFIOER OF THE MENTAL
DISEASE RESEARCH DEPARTMENT-The Secretary, The University, DISEASE RESEARCH DEPAR
Birmingham (September 1 ).

UNIVERSITY ChaIR of CHEMISTRY, tenable at the Royal Cancer Hospital-The Academic Registrar, University of London, Richmond College, Richmond, Surrey (September 1).

Physioal Chemist and a Mineralogist or Geo-chemist For RESEARCH WORK INTO MATERTALS AND PROCESSES OF THE CERAMIC INDCSTRIES-The Director of Research, British Pottery Research Association, Queens Road, Penkhull, Stoke-on-Trent.

Graduate (MAN or WOMAN) in ScIENCE or equivalent in Engineering, and a GRADEATE (MAN OR WOMAN) IN SCIENCE including Biology, and able to assist in General Subjects, at the Mexborough Schofieid Yorks.

\section{REPORTS and other PUBLICATIONS}

(not included in the monthly Books Supplement)

\section{Great Britain and Ireland}

Reports of the Council and Auditors of the Zoological Society of London for the Year 1941. Pp. 38. (London: Zoological Society of
[58

Proceedings of the Royal Society of Edinburgh. Section B (Biology), Vol. 61, Part 3, No. 22: Deflciency Effects of Ultra-violet Light in Drosophila melanogaster. By Dr. B. M. Slizynski. Pp. 297-315. (Edinburgh and London: Oliver and Boyd.) 1s.6d. [58

\section{Other Countries}

Commonwealth of Australia: Councll for Scientific and Industrial Research. Bulletin No. 144: Interference in a Wind-Tunnel of Octagonal Section. By G. K. Batchelor. Pp. 24. Bulletin No. 147: Enzootic Ataxia and Copper Deficiency of Sheep in Western Australia: By H. W. Bennetts and A. B. Beck. Pp. 52. Pamphlet No. 110 The Main Virus Diseases of the Potato in Victoria. By Dr. J. G.
Bald and A. T. Pugsley. Pp. $40+4$ plates. (Melbourne : Govern-
[287

[287 Indian Forest Bulletin No. 17 (Silviculture, New Series): A Note on Semal (Bombax malabaricum D.C.). By Jagdamba Prasad. Pp $\mathrm{v}+15+3$ plates. (Delhi : Manager of Publications.) 14 annas
18. 3 d. 